\title{
Photodynamic Therapy Mediated by a Novel Chlorin Derivative, TONS 501-Na, in EMT6 cells
}

\author{
TOMOHIRO OSAKI ${ }^{1}$, ISAO SAKATA ${ }^{2}$, YOSHIHIRO UTO ${ }^{3}$, KAZUO AZUMA $^{1}$, YUSUKE MURAHATA ${ }^{1}$, \\ TAKESHI TSUKA ${ }^{1}$, NORIHIKO ITOH ${ }^{1}$, TOMOHIRO IMAGAWA ${ }^{1}$ and YOSHIHARU OKAMOTO ${ }^{1}$ \\ ${ }^{1}$ Department of Veterinary Clinical Medicine, School of Veterinary Medicine, \\ Tottori University, Tottori, Japan; \\ ${ }^{2}$ Porphyrin Laboratory, Okayama, Japan; \\ ${ }^{3}$ Faculty of Bioscience and Bioindustry, Tokushima University, Tokushima, Japan
}

\begin{abstract}
Background: The lipophilic photosensitizer, TONS 501 , is a novel porphyrin-derived methyl ester that was developed for photodynamic antimicrobial chemotherapy. This study developed a hydrophilic and anionic porphyrin salt of this compound (TONS 501-Na) for use in photodynamic therapy (PDT). This chlorin derivative is synthesized from the protoporphyrin IX dimethyl ester. Materials and Methods: We investigated the in vitro cytotoxic effects of TONS 501-Namediated PDT on EMT6 mouse breast cancer cells. EMT6 cells were incubated with $0-100 \mu \mathrm{g} / \mathrm{ml}$ TONS 501-Na for $24 \mathrm{~h}$ prior to replacing the culture medium and exposing the cells to $6 \mathrm{~mW} / \mathrm{cm}^{2}$ diode laser irradiation at $0-13 \mathrm{~J} / \mathrm{cm}^{2}$ to induce PDT. Morphological changes and cell viability were evaluated $24 \mathrm{~h}$ after PDT. The percentages of apoptotic cells were evaluated $4 h$ and $24 h$ after PDT. Results: The concentrations of TONS 501-Na that killed 50\% of EMT6 cells after exposure to light doses of 0, 0.4, 3, 6, or $13 \mathrm{~J} / \mathrm{cm}^{2}$ were $84.6,33.2,18,8.2$, and $2.2 \mu \mathrm{g} / \mathrm{ml}$, respectively. Tumor cells exposed to PDT showed chromatin condensation and fragmentation. The percentages of apoptotic cells increased in a TONS 501-Na concentration-dependent manner in the $P D T$ group, and were significantly higher than those in the control group or in cells treated with TONS 501-Na or laser irradiation alone. Conclusion: TONS 501-Na-mediated PDT induced mouse breast cancer cell death in a concentrationdependent manner. Future studies should evaluate the in vivo pharmacokinetics, tissue distribution, and photodynamic effects of TONS 501-Na.
\end{abstract}

Correspondence to: Tomohiro Osaki, DVM, Ph.D., Joint Department of Veterinary Clinical Medicine, Faculty of Agriculture, Tottori University, 4-101 Koyama-Minami, Tottori 680-8553, Japan. Tel: +81857315434, Fax: +81857315434, e-mail: tosaki@muses.tottoriu.ac.jp

Key Words: Apoptosis, photodynamic therapy, TONS 501-Na.
Breast cancer is now the most frequently diagnosed cancer and one of the most deadly diseases for women (1-3). With improving breast screening more breast cancers are being diagnosed early stage and therefore often require less extensive cancer treatment (3). Photodynamic therapy (PDT) is a minimal-invasive cancer treatment. The key agent in PDT is the photosensitizer, a compound that is excited by light and converted to a triplet excited state $(4,5)$. An agent known as EC036 [13,17-bis (1-carboxyethyl)-3-(1,3-dioxan-2-yl) methylidene-8-ethenyl-2-hydroxy-2,7,12,18-tetramethylchlorin, dimethyl ester] is a hydrophobic photosensitizer with a relatively low molecular weight. TONS $501,[13,17$-bis (1carboxypropionyl) carbamoylethyl-3-ethenyl-2-hydroxy-3hydroxyimino ethlidene-2,7,12,18-tetramethyl-porphyrin sodium salt], is a novel hydrophobic photosensitizer (MW: $640)$ that is a regioisomer of EC036 (6). TONS 504 [13,17-bis (1-carboxyethyl) carbamoyl (3-methylpyridine)-3-(1,3-dioxane2-yl) methylidene-8-ethenyl-2-hydroxy-2, 7, 12, 18-tetramethyl chlorine, diN-methyl iodide], an also novel cationic hydrophilic photosensitizer (MW: 1,116.9), was synthesized from protoporphyrin IX dimethyl ester in a five-step process $(7,8)$. In the present study, a hydrophilic and anionic porphyrin salt known as TONS 501-Na (MW: 696.8) was developed for use in photodynamic therapy (PDT). TONS 501-Na (Figure 1) is a chlorin derivative that can be synthesized from the protoporphyrin IX dimethyl ester using a four-step process (9). Herein, we investigated the cytotoxic effects of TONS 501-Na-mediated PDT on the EMT6 mouse breast cancer cell line in vitro.

\section{Materials and Methods}

Cell line and culture conditions. EMT6 mouse mammary tumor cells (supplied by Dr. Shinichiro Masunaga, Kyoto University, Japan) were maintained as an adherent monolayer culture in RPMI 1640 medium (Invitrogen, Carlsbad, CA, USA) supplemented with $10 \%$ heat-inactivated fetal bovine serum (Nichirei Biosciences Inc., Tokyo, Japan) and antibiotics $(5 \mathrm{mg} / \mathrm{ml}$ penicillin, $5 \mathrm{mg} / \mathrm{ml}$ 
streptomycin, and $10 \mathrm{mg} / \mathrm{ml}$ neomycin; Invitrogen) in the presence of $5 \% \mathrm{CO}_{2}$ at $37^{\circ} \mathrm{C}$.

The cells were harvested from near-confluent cultures by brief exposure to a solution containing $0.25 \%$ trypsin and $1 \mathrm{mmol} / \mathrm{l}$ ethylenediaminetetraacetic acid (tetrasodium salt) solution with phenol red (Invitrogen). Trypsinization was stopped using RPMI 1640 containing $10 \%$ fetal bovine serum. The cells were centrifuged and re-suspended in RPMI 1640. Trypan blue staining was used to assess cell viability.

Chemicals. MitoTracker Green FM and LysoTracker Yellow FM were obtained from Thermo Fisher Scientific Inc. (Waltham, MA, USA). The Cell Counting Kit-8 was purchased from Dojindo (Kumamoto, Japan) and the Promokine Apoptotic/Necrotic/Healthy cells detection kit was from PromoCell (Heidelberg, Germany). The Muse ${ }^{\circledR}$ Oxidative Stress Kit and the Muse ${ }^{\circledR}$ Annexin V and Dead Cell Assay Kit were purchased from EMD Millipore Co (Billerica, MA, USA).

Subcellular localization of TONS 501-Na. The intracellular distribution of TONS 501-Na was monitored using an Olympus Fluoview FV1000 (Olympus, Tokyo, Japan) confocal laser scanning microscope. EMT6 cells were seeded in 8-well cell culture slides (SPL Life Sciences, Gyeonggi-do, Korea) and incubated in RPMI 1640 medium for $24 \mathrm{~h}$ at $37^{\circ} \mathrm{C}$. Then, the cells were incubated with TONS 501-Na at a final concentration of $20 \mu \mathrm{g} / \mathrm{ml}$ for $4 \mathrm{~h}$, followed by co-incubation with $100 \mathrm{nM}$ MitoTracker Green FM and $50 \mathrm{nM}$ LysoTracker Yellow (HCK-123) for an additional $30 \mathrm{~min}$ in culture medium before confocal laser scanning microscopy. The fluorescence of TONS 501-Na was detected using 543-nm excitation by a heliumneon $(\mathrm{G})$ laser and a 560-nm long pass filter. The fluorescent signals of MitoTracer Green FM and LysoTracker Yellow (HCK-123) were detected by excitation at $488 \mathrm{~nm}$ using an argon laser, a 560-nm dichroic mirror, and a 505-525-nm band pass barrier filter.

Evaluation of the cytotoxic effects of TONS 501-Na and light in EMT6 cells. We seeded 4-5×104 EMT6 cells into each well of 96well plates (Corning Inc., New York, NY, USA) and incubated overnight. The cells were then incubated with various concentrations of TONS 501-Na for $24 \mathrm{~h}$ at $37^{\circ} \mathrm{C}$. After washing with fresh media, the cells were irradiated with 664-nm light emitted by a semiconductor laser. PDT was performed at $6 \mathrm{~mW} / \mathrm{cm}^{2}$ in cells exposed to six concentrations of TONS 501-Na $(0,1,3,10$, 30 , or $100 \mu \mathrm{g} / \mathrm{ml})$, using five light doses $\left(0,0.4,3,6\right.$, or $\left.13 \mathrm{~J} / \mathrm{cm}^{2}\right)$. The cells were then incubated for $24 \mathrm{~h}$ in the dark prior to examining cell viability using the Cell Counting Kit-8, according to the manufacturer's instructions.

Analysis of cell death. We seeded 4-5×104 EMT6 cells into 35-mm Petri dishes (Nunc, Ltd., Roskilde, Denmark) containing $2 \mathrm{ml}$ of cultivation medium. After $24 \mathrm{~h}$ of incubation, the dishes were divided into the following four groups: (1) the control group (no treatment), (2) the TONS 501-Na group (treated with $10 \mu \mathrm{g} / \mathrm{ml}$ TONS 501-Na), (3) the laser group (irradiated with light dose of 13 $\mathrm{J} / \mathrm{cm}^{2}$ ), and (4) the PDT group (treated with $10 \mu \mathrm{g} / \mathrm{ml}$ TONS 501$\mathrm{Na}$, and then irradiated with light dose of $13 \mathrm{~J} / \mathrm{cm}^{2}$ ).

The cells were incubated with $10 \mu \mathrm{g} / \mathrm{ml}$ TONS 501-Na for $24 \mathrm{~h}$. After washing with fresh media, the cells were irradiated with 664$\mathrm{nm}$ laser light $\left(6 \mathrm{~mW} / \mathrm{cm}^{2}, 13 \mathrm{~J} / \mathrm{cm}^{2}\right)$. After $24 \mathrm{~h}$ PDT, the cells were stained using the Promokine Apoptotic/Necrotic/Healthy cell

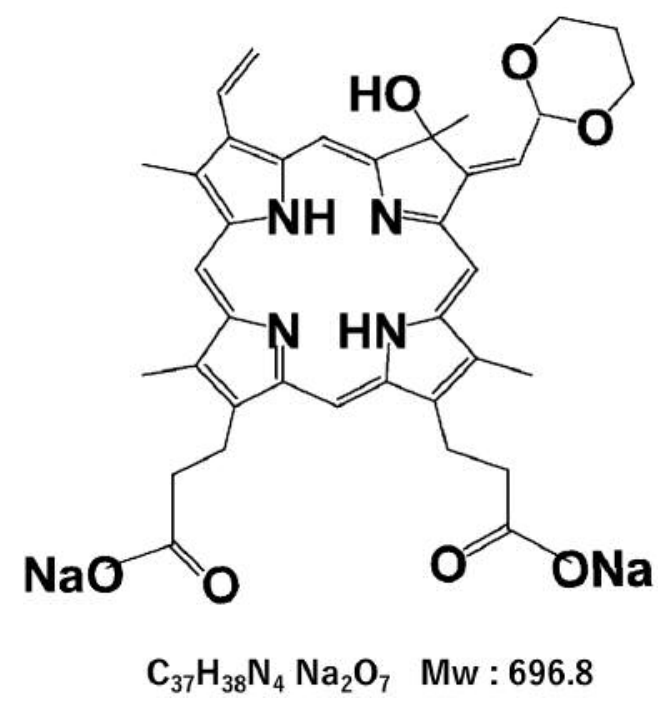

Figure 1. Chemical structure of the photosensitizer, TONS 501-Na.

detection kit, according to the manufacturer's instructions. The cells were stained with Hoechst $3334224 \mathrm{~h}$ after laser irradiation. Nuclear morphology was examined using an Olympus BX51 (Olympus, Tokyo, Japan). To assess apoptosis and necrosis, the cells were stained with annexin V-fluorescein isothiocyanate (FITC) and ethidium homodimer III (EthD-III) $24 \mathrm{~h}$ after laser irradiation. Nuclear morphology was examined using an Olympus Fluoview FV1000. The cells were analyzed by fluorescence microscopy using the FITC and Texas Red filter setting.

Analysis of apoptosis. We seeded 4-5 $\times 10^{4}$ EMT6 cells into $35-\mathrm{mm}$ Petri dishes containing $2 \mathrm{ml}$ of cultivation medium. After $24 \mathrm{~h}$ of incubation, the dishes were divided into the following four groups: (1) the control group (no treatment), (2) the TONS 501-Na group (treated with $10 \mu \mathrm{g} / \mathrm{ml}$ TONS 501-Na), (3) the laser group (irradiated with light dose of $13 \mathrm{~J} / \mathrm{cm}^{2}$ ), and (4) the PDT group (treated with $10 \mu \mathrm{g} / \mathrm{ml}$ TONS 501-Na, and then irradiated with light dose of $0.4,3,6$, or $13 \mathrm{~J} / \mathrm{cm}^{2}$ ).

The cells were incubated with $10 \mu \mathrm{g} / \mathrm{ml}$ TONS 501-Na for $24 \mathrm{~h}$. After washing with fresh media, the cells were irradiated with 664-nm light $\left(0,0.4,3,6\right.$, or $\left.13 \mathrm{~J} / \mathrm{cm}^{2}\right)$. Apoptosis was assessed $4 \mathrm{~h}$ and $24 \mathrm{~h}$ after laser irradiation using the Muse ${ }^{\circledR}$ Annexin V and Dead Cell Assay Kit, according to the manufacturer's instructions. This assay utilized annexin $\mathrm{V}$ to detect phosphatidylserine on the external membrane of apoptotic cells.

Statistical analysis. Data were analyzed using Dunn's multiple comparison test. A $p$-value $<0.05$ was considered statistically significant. Statistical analyses were performed using GraphPad Prism version 6 (GraphPad Software Inc., La Jolla, CA, USA).

\section{Results}

TONS 501-Na subcellular localization. Confocal micrographs of EMT6 cells exposed to TONS 501-Na and fluorescent molecular probes are shown in Figure 2. TONS 

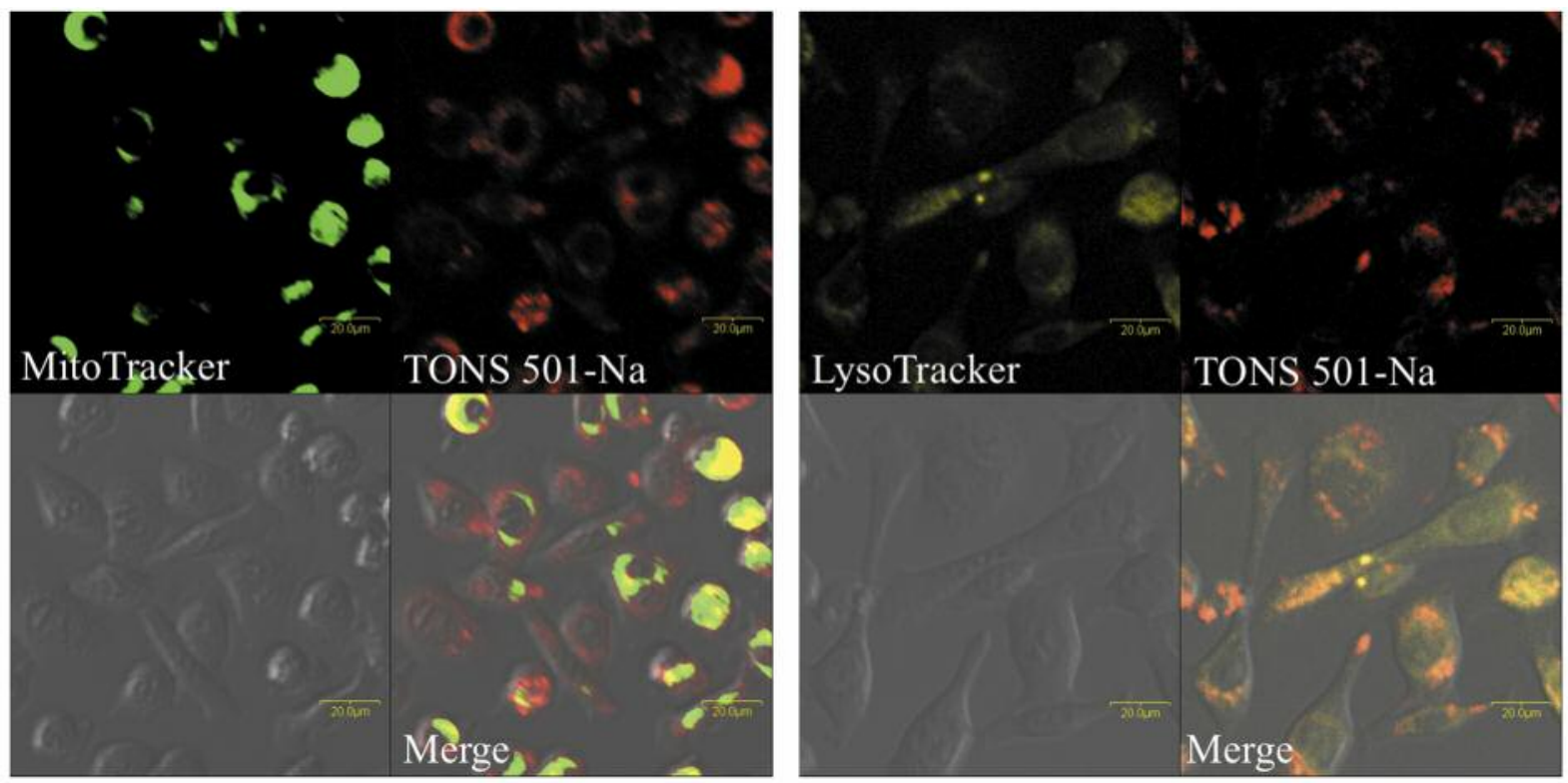

Figure 2. Subcellular localization of TONS 501-Na was characterized using confocal laser scanning microscopy, showing localization to the mitochondria and lysosomes.

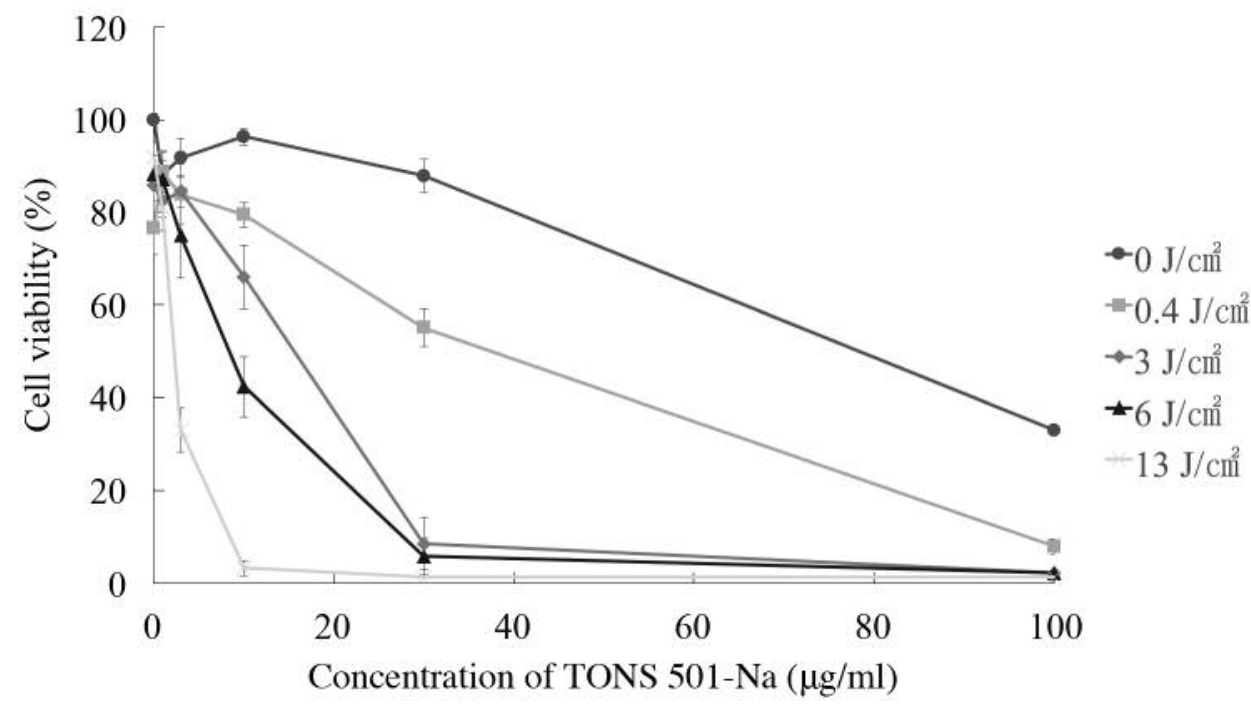

Figure 3. The cytotoxicity of TONS 501-Na-mediated PDT on EMT6 cells. EMT6 cell survival was significantly reduced as the concentration of TONS 501-Na increased. The $L D_{50}$ values for TONS 501-Na in EMT6 cells exposed to light intensities of 0, 0.4, 3, 6, or 13 J/cm ${ }^{2}$ were 84.6, 33.2, $18,8.2$, and $2.2 \mu \mathrm{g} / \mathrm{ml}$, respectively.

501-Na was localized in the mitochondria and lysosomes. No fluorescence was detected in the cell nuclei.

TONS 501-Na and light-induced cytotoxicity in EMT6 cells. Figure 3 shows the viability of EMT6 cells, $24 \mathrm{~h}$ after PDT. EMT6 cell survival was dependent on the concentration of TONS 501-Na, with significantly lower survival rates at higher TONS 501-Na concentrations. No cell death was observed in cells treated with less than $30 \mu \mathrm{g} / \mathrm{ml}$ TONS 501-Na in the absence of laser irradiation. In contrast, almost all of the cells that were pre-treated with $30 \mu \mathrm{g} / \mathrm{ml}$ TONS 501-Na were killed following exposure to light at intensities over $3 \mathrm{~J} / \mathrm{cm}^{2}$.

We calculated the concentration of TONS 501-Na that was required to kill $50 \%$ of the cells $\left(\mathrm{LD}_{50}\right)$. The $\mathrm{LD}_{50}$ values for EMT6 cells exposed to light doses of $0,0.4,3,6$, or $13 \mathrm{~J} / \mathrm{cm}^{2}$ were $84.6,33.2,18,8.2$, and $2.2 \mu \mathrm{g} / \mathrm{mL}$, respectively. 

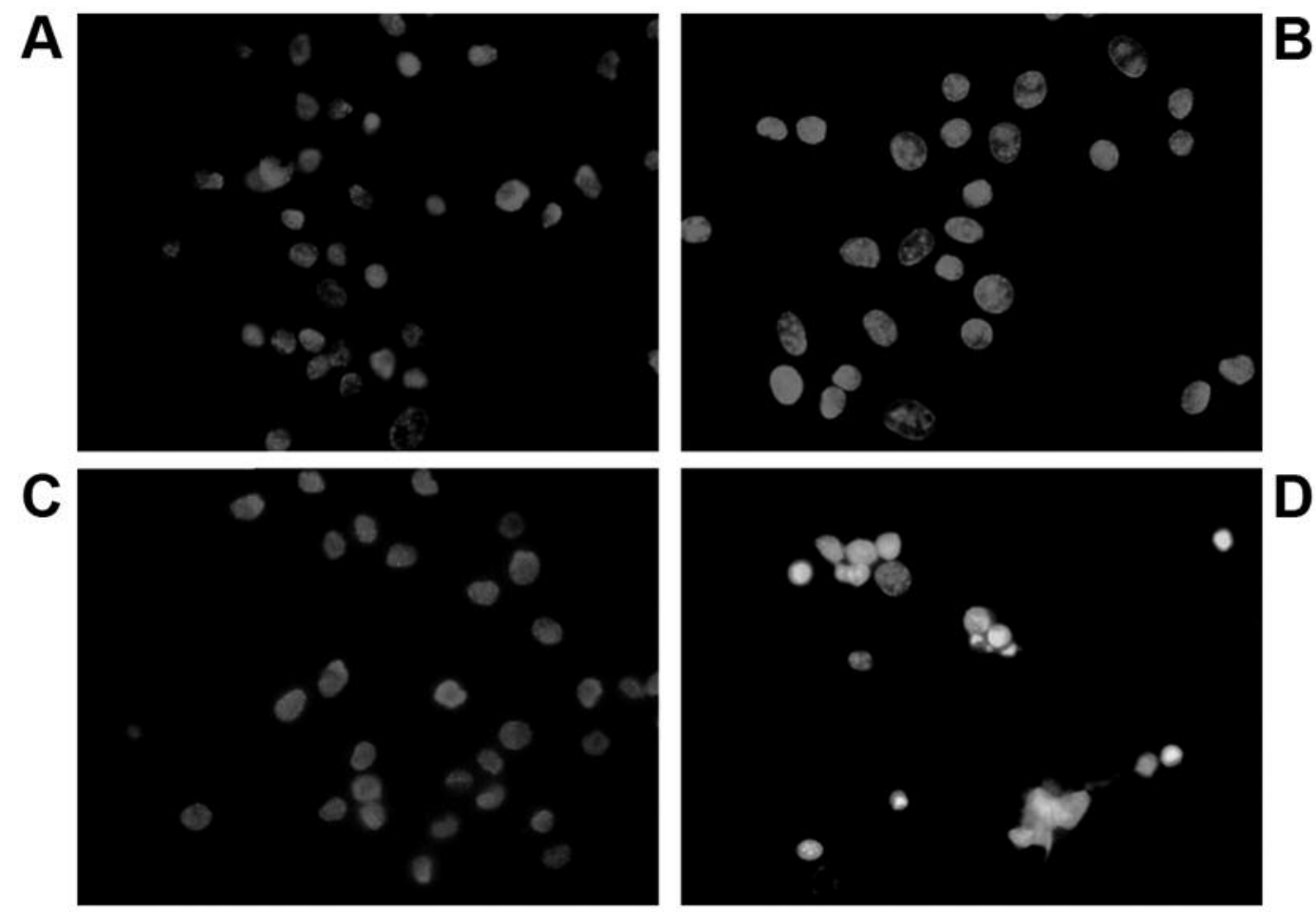

Figure 4. EMT6 cells were incubated with $10 \mu \mathrm{g} / \mathrm{ml}$ TONS 501-Na for $24 \mathrm{~h}$ prior to washing and exposure to 664-nm laser light, and incubated for a further 24 h before staining with Hoechst 33342. No signs of apoptosis were visible in the control (A), TONS 501-Na (B), or laser groups (C), while cells exposed to PDT (D) showed chromatin condensation.

Apoptotic versus necrotic cell death. Figure 4 shows EMT6 cells stained with Hoechst 33342, 24 h after PDT. Hoechst 33342 was used to evaluate apoptosis since it allowed visualization of the nuclear condensation and fragmentation that is characteristic of apoptosis. No signs of apoptosis were visible in the control, TONS 501-Na, and laser groups. Cells in the PDT groups showed chromatin condensation.

Figure 5 shows images of EMT6 cells stained for annexin V-FITC and EthD-III, $24 \mathrm{~h}$ after PDT. The PDT group showed positive signals for annexin $\mathrm{V}$ and EthD-III. This indicated that phosphatidylserine translocation had occurred and that plasma membrane integrity was lost in these cells, indicating that they were either in late apoptosis or early stage necrosis.

Analysis of apoptosis. Figure 6 shows the percentage of apoptotic EMT6 cells at $4 \mathrm{~h}$ and $24 \mathrm{~h}$ after PDT. At $24 \mathrm{~h}$ after PDT, the percentage of apoptotic cells in the PDT $13 \mathrm{~J} / \mathrm{cm}^{2}$ group was significantly higher than those observed in the control group or in the $10 \mu \mathrm{g} / \mathrm{ml}$ TONS $501-\mathrm{Na}$ group ( $p=0.0416$ and $p=0.0467$, respectively). The percentage of apoptotic cells in the PDT group increased in a light dosedependent manner. The percentage of $\mathrm{ROS}^{+}$cells observed at $24 \mathrm{~h}$ after PDT was greater than that observed $4 \mathrm{~h}$ after PDT.

\section{Discussion}

PDT mediated by TONS 501 ointment was reported to produce a potent anti-tumor effect on mouse skin papilloma. It is not possible to inject TONS 501 systemically because it is a lipophilic photosensitizing compound (6). Therefore, a hydrophilic photosensitizer is required for systemic administration. Sakata et al. (9), thus, produced TONS 501$\mathrm{Na}$, which is a hydrophilic photosensitizer.

The present study found that TONS 501-Na-mediated PDT induced cell death in a mouse breast cancer cell line in a concentration-dependent manner. A previous PDT study using a different photosensitizer, porfimer sodium, identified an $\mathrm{LD}_{50}$ of about $10 \mu \mathrm{g} / \mathrm{ml}$ with a laser power of $12 \mathrm{~J} / \mathrm{cm}^{2}$ in human biliary cancer cells (10). In another study of glioma cell lines, the $\mathrm{LD}_{50}$ values for talaporfin sodium were $5-7 \mu \mathrm{g} / \mathrm{ml}$ in A172 and U251 cells, and $20-25 \mu \mathrm{g} / \mathrm{ml}$ in T98G cells, at a laser power of $10 \mathrm{~J} / \mathrm{cm}^{2}$ (11). In the present study, the $\mathrm{LD}_{50}$ for TONS 501-Na in EMT6 cells was $2.2 \mu \mathrm{g} / \mathrm{ml}$ at a laser power of $13 \mathrm{~J} / \mathrm{cm}^{2}$. Although the cell lines employed were different, these findings indicated that TONS 501-Na may be more effective than other porfimer sodium.

The present confocal laser scanning microscopy study indicated that TONS 501-Na accumulated in mitochondria 

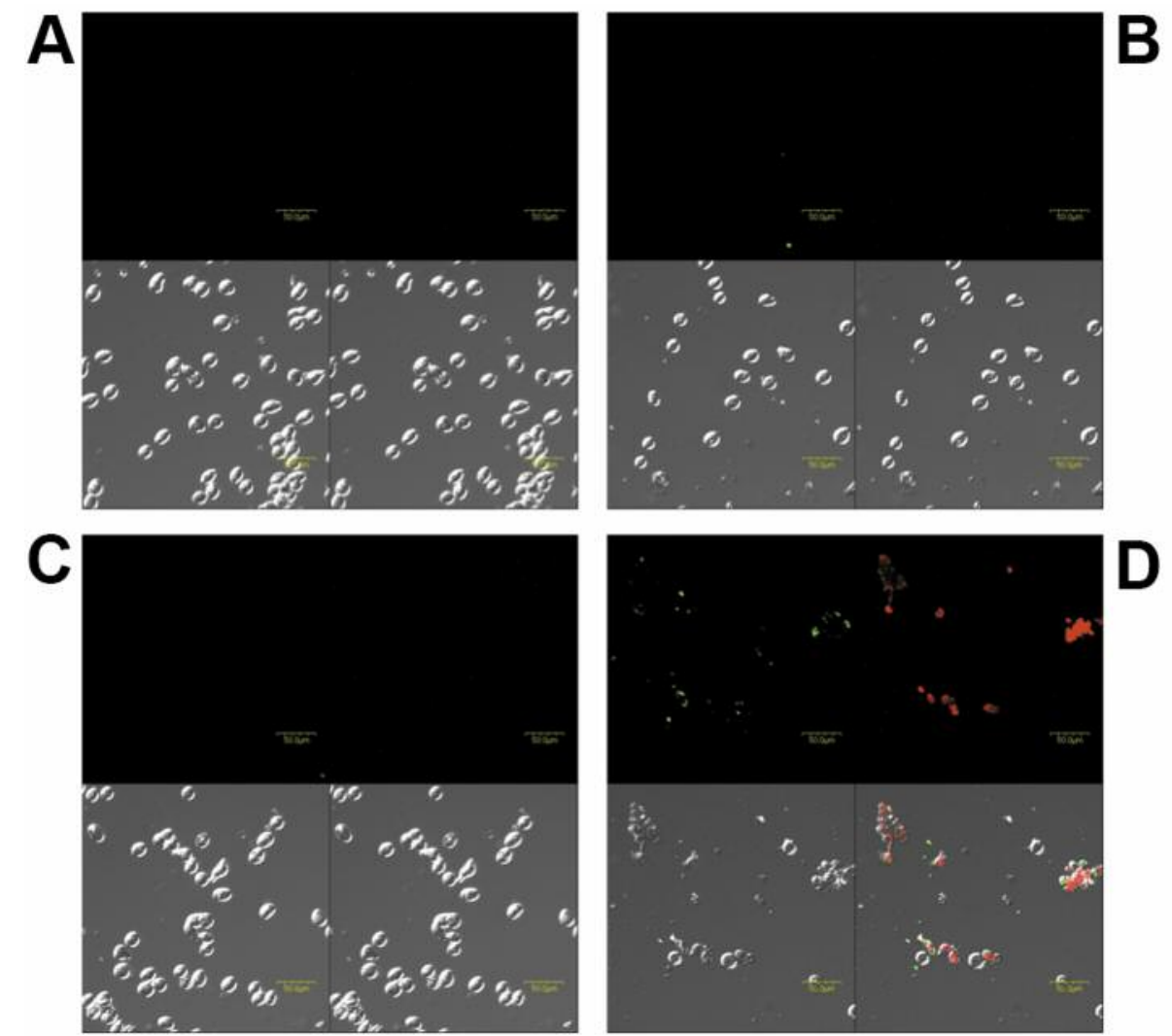

Figure 5. EMT6 cells were incubated with $10 \mu \mathrm{g} / \mathrm{ml}$ TONS 501-Na for $24 \mathrm{~h}$ prior to washing and exposure to 664-nm laser light, and incubated for a further $24 \mathrm{~h}$ before staining for annexin V (green) and EthD-III (red). (A) Control, (B) TONS 501-Na, (C) laser groups. The PDT group (D) showed positive signals for annexin $V$ and EthD-III, indicating that these cells were either in late apoptosis or early-stage necrosis.

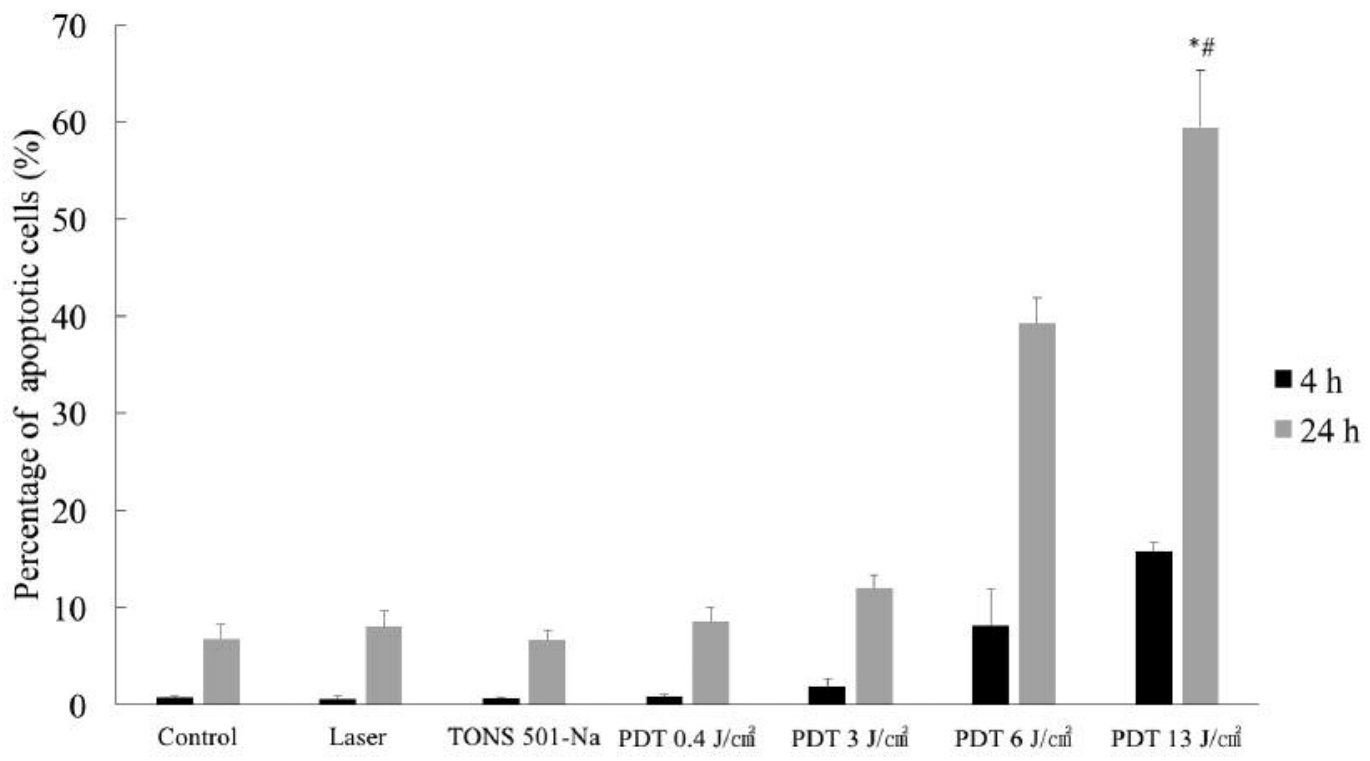

Figure 6. Apoptosis was analyzed in EMT6 cells that had been incubated with $10 \mu \mathrm{g} / \mathrm{ml}$ TONS 501-Na for 24 h prior to washing and exposure to 664-nm laser light $\left(0,0.4,3,6\right.$, or $\left.13 \mathrm{~J} / \mathrm{cm}^{2}\right)$; *p=0.0416 (control vs. PDT $\left.13 \mathrm{~J} / \mathrm{cm}^{2}\right)$; \#p=0.0467 (TONS vs. PDT $\left.13 \mathrm{~J} / \mathrm{cm}^{2}\right)$. 
and lysosomes. Exposure of EMT6 cells to TONS 501-NaPDT increased the proportion of cells showing features indicative of late apoptosis or early stage necrosis. It was reported that lysosomal photodamage can increase PDT efficiency by inducing subsequent mitochondrial damage $(12,13)$. Therefore, our findings indicated that cell death induced by TONS 501-Na-PDT may occur via direct mitochondrial damage and/or indirect lysosomal damage.

TONS 501-Na-mediated PDT induced apoptotic cell death in a light dose-dependent manner. The percentages of apoptotic cells increased with time. PDT-generated ROS include superoxide anions, hydrogen peroxide, and hydroxyl radicals (14). Depending on the type of ROS generated, PDT was reported to stimulate autophagy (15) that either acted in a cytoprotective manner or induced autophagic cell death (16). It was also reported that the rates of autophagy and apoptosis were dependent on the cancer cell type, the photosensitizer employed, and the light intensity (17). TONS 501-Na-mediated PDT might therefore induce both apoptotic and autophagic cell death in EMT6 cells. To investigate this further, additional evaluation of autophagosome formation should be conducted in future studies of TONS 501-Na-mediated PDT.

In conclusion, TONS 501-Na-mediated PDT induced cell death in a mouse breast cancer cell line in a dose-dependent manner. Future studies are needed to evaluate the in vivo pharmacokinetics, tissue distribution, and photodynamic effects of TONS 501-Na for mouse model of EMT6 breast cancer.

\section{Acknowledgements}

The Authors would like to thank M. Ono for technical assistance with the experiments.

\section{Conflicts of Interest}

The Authors certify that there is no conflict of interest with any commercial organization regarding the material discussed in the manuscript.

\section{References}

1. George BP and Abrahamse H: A Review on Novel Breast Cancer Therapies: Photodynamic Therapy and Plant Derived Agent Induced Cell Death Mechanisms. Anticancer Agents Med Chem 16: 793-801, 2016.

2 Jemal A, Bray F, Center MM, Ferlay J, Ward E and Forman D: Global cancer statistics: CA Cancer J Clin 61: 69-90, 2011.

3 Banerjee SM, MacRobert AJ, Mosse CA, Periera B, Bown SG and Keshtgar MR: Photodynamic therapy: Inception to application in breast cancer. Breast 31: 105-113, 2017.
4 Bacellar IO, Tsubone TM, Pavani C and Baptista MS: Photodynamic efficiency: from molecular photochemistry to cell death. Int J Mol Sci 16: 20523-20559, 2015.

5 Triesscheijn M, Baas P, Schellens JH and Stewart FA: Photodynamic therapy in oncology. Oncologist 11: 1034-1044, 2006.

6 Takahashi H, Nakajima S, Asano R, Nakae Y, Sakata I and Iizuka H: Photodynamic therapy using a novel photosensitizer, TONS501, is similarly effective to ALA and EC036 photodynamic therapy on DMBA- and TPA-induced mouse skin papilloma. J Dermatol Sci 66: 221-224, 2012.

7 Latief MA, Chikama T, Shibasaki M, Sasaki T, Ko JA, Kiuchi Y, Sakaguchi T and Obana A: Antimicrobial action from a novel porphyrin derivative in photodynamic antimicrobial chemotherapy in vitro. Lasers Med Sci 30: 383-387, 2015.

8 Latief MA, Chikama T, Ko JA, Kiuchi Y, Sakaguchi T and Obana A: Inactivation of acyclovir-sensitive and -resistant strains of herpes simplex virus type 1 in vitro by photodynamic antimicrobial chemotherapy. Mol Vis 21: 532-537, 2015.

9 Sakata I: Skin disease treatment agent. JP5179245B2. 2013-0410 .

10 Nonaka T, Nanashima A, Nonaka M, Uehara M, Isomoto H, Asahina I and Nagayasu T: Analysis of apoptotic effects induced by photodynamic therapy in a human biliary cancer cell line. Anticancer Res 30: 2113-2118, 2010.

11 Tsutsumi M, Miki Y, Akimoto J, Haraoka J, Aizawa K, Hirano $\mathrm{K}$ and Beppu M: Photodynamic therapy with talaporfin sodium induces dose-dependent apoptotic cell death in human glioma cell lines. Photodiagnosis Photodyn Ther 10: 103-110, 2013.

12 Nagata S, Obana A, Gohto Y and Nakajima S: Necrotic and apoptotic cell death of human malignant melanoma cells following photodynamic therapy using an amphiphilic photosensitizer ATXS10(Na). Lasers Surg Med 33: 64-70, 2003.

13 Kessel D and Reiners JJ: Promotion of proapoptotic signals by lysosomal photodamage. Photochem Photobiol 9: 931 936, 2015.

14 Ormond $\mathrm{AB}$ and Freeman HS: Dye sensitizers for photodynamic therapy. Materials 6: 817 840, 2013.

15 Sasnauskiene A, Kadziauskas J, Vezelyte N, Jonusiene V and Kirveliene V: Apoptosis, autophagy and cell cycle arrest following photodamage to mitochondrial interior. Apoptosis 14 : 276-286, 2009.

16 Scherz-Shouval R and Elazar Z: ROS, mitochondria and the regulation of autophagy. Trends Cell Biol 17: 422 427, 2007

17 Mroz P, Yaroslavsky A, Kharkwal GB and Hamblin MR: Cell death pathways in photodynamic therapy of cancer. Cancers (Basel) 3: 2516-2539, 2011. 